\title{
PTPN1 wt Allele
}

National Cancer Institute

\section{Source}

National Cancer Institute. PTPN1 wt Allele. NCI Thesaurus. Code C49522.

Human PTPN1 wild-type allele is located within 20q13.1-q13.2 and is approximately 74 kb in length. This allele, which encodes tyrosine-protein phosphatase non-receptor type 1 protein, is involved in the dephosphorylation of protein-tyrosine phosphates. Functional PTPN1 gene polymorphisms are associated with susceptibility to insulin resistance. 